\title{
Management of Zakah Distribution: Empirical Evidence From Indonesia
}

\author{
Rahmatina A. Kasri ${ }^{1^{*}}$ \\ ${ }^{1}$ University of Indonesia, Depok, Indonesia
}

\begin{abstract}
Despite the importance of zakah distribution, few studies attempt to evaluate practices in managing the distribution. The paper, thus, aims to explore approaches and evaluate practices in managing the zakah distribution. It employs qualitative research approach with semi-structured interviews with key management personnel of seven largest zakah organizations in Indonesia. The main finding identifies two approaches in distributing zakah in Indonesia, namely consumptive disbursement and productive utilization approaches. Each approaches is different in terms of purposelexpected impact, types/nature of programs and methods of distributing the zakah proceeds. It is also found that different types of zakah organizations tend to focus on different zakah distribution approach. Moreover, some challenges are identified particularly in relation to selection/coverage of mustahik and threat or 'competition' in distributing zakah funds. Overall, the study highlights the increasing relevance of productive utilization approach as well as importance of enhancing outreach and availability of information related to zakah programs (including through online platforms) and continuously educate all zakah stakeholders. The findings are expected to provide insights in managing zakah distribution in Indonesia and ultimately in increasing effectiveness of zakah institution to achieve its objectives.
\end{abstract}

Keywords: Indonesia, qualitative research, zakah distribution, zakah management, zakah organizations

\section{INTRODUCTION}

Zakah is one of the five pillars of Islam. Literally, zakah means 'growth', 'increase', or 'purity' of wealth. While from fiqh perspective, it specifically refers to the predetermined share of wealth to be distributed among the deserving categories prescribed by God (Al-Qardawi, 2000). Several conditions have to be fulfilled before zakah is payable. This includes, among others, the type of assets (i.e. only assets that are acquired for the purpose of creating wealth is subject to zakah), haul (completion of one full Islamic year) and nisab (minimum threshold stipulated for each type of the assets).

Zakah is deemed to be an important economic tool to mobilize assets for the purpose of economic growth, poverty alleviation and empowerment of eight specific groups in society (Saad and Haniffa, 2014). As zakah institution is expected to contribute in economic growth and poverty alleviation, the question on how zakah revenues/proceeds are utilized become crucial. This issue is important

* Corresponding author. Email address: rahmatina@ui.ac.id 
not only because improper use of zakah proceeds will result in failure to achieve the main objectives of zakah institution, but also because misused of zakah funds might endanger trust and beliefs of Muslim society on the significance of zakah institution in Islamic teaching and Islamic society as it is one of the five pillars in Islam. Therefore, the issue of effective management of zakah distribution is crucial to be addressed.

The issue of zakah distribution, however, seems to be overlooked by most of zakah related studies. Currently, majority of studies related to zakah seems to focus on administration/colection of zakah (see, for instance, Kahf 2000, Samad and Glen 2010, Sari et al 2013), zakah and poverty alleviation (see, among others, Ahmed 2004, Beik 2013, Kasri 2015) as well as zakah and Islamic microfinance (see, for instance, Obaidullah and Shirazi 2014, Ibrahim and Ghazali 2015, Shaikh and Shaikh 2017). The issue on zakah distribution sometime appears in the discussion under the abovementioned topics. Nevertheless, as far as our concern, few studies specifically and thoroughly addressed the issue of zakah distribution in their analysis.

With this perspective, the main objective of this paper is to explore approaches and evaluate practices in distributing zakah in Indonesia. Indonesia is chosen as a case study since it is one of the largest Muslim countries in the world. Additionally, since there are three types of zakah organizations in the country, it also attempts to analyse whether different types of zakah organizations focus on different approaches in distributing zakah proceeds. It also explores challenges in managing zakah distribution in Indonesia in order to provide more insights into the management practices.

To achieve the research objectives, the study employs inductive and qualitative research approach. It collects primary qualitative data from semistructured interviews with 23 key management personnel, mostly Directors and Operational Managers, of seven largest zakah organizations in Indonesia. The results are subsequently analysed by utilizing thematic analysis.

Following the introductory section, the structure of this paper is as follow. Section two reviews some theoretical aspects and previous studies related to zakah distribution. Section three explains the data and methods used in the study. Section four presents the results, while section five discusses the findings. The last section concludes the study and provide some recommendations for relevant zakah stakeholders.

\section{LITERATURE STUDY}

Earlier literature related to zakah distribution generally discusses several aspects of zakah distribution, such as aspects related to recipients of zakah or mustahik (definition/selection of mustahik, share of mustahik, etc.), form of distribution and time of distribution. In terms of the recipients of zakah, the Qur'an clearly mentioned that, "The charities (zakah) are for the poor, needy, those employed to administer the funds, those whose hearts have reconciled to the truth, freeing slaves (those in bondage), those indebted, in the cause of God, and the wayfarer in need..." (QS 9:60). Thus, zakah should only be given to the eight groups of people (see Table 1 for the definition of each group). 
Table 1 Types of Zakah Recipients (Mustahik)

\begin{tabular}{|c|c|c|}
\hline No & Group & Definition \\
\hline 1 & The poor (fuqara) & $\begin{array}{l}\text { Persons whose wealth/income fall short of } \\
\text { satisfying basic needs. }\end{array}$ \\
\hline 2 & $\begin{array}{l}\text { The needy } \\
\text { (masakin) }\end{array}$ & $\begin{array}{l}\text { Persons whose wealth/income fall short of } \\
\text { satisfying essential needs, but cannot obtain } \\
\text { sufficient sustenance. }\end{array}$ \\
\hline 3 & $\begin{array}{l}\text { The administrators } \\
\text { of zakah (amil) }\end{array}$ & $\begin{array}{l}\text { Persons responsible for the management } \\
\text { (collection and distribution) of zakah proceeds. }\end{array}$ \\
\hline 4 & $\begin{array}{l}\text { The converts } \\
\text { (muallaf) }\end{array}$ & $\begin{array}{c}\text { Persons who have recently been brought to Islam, } \\
\text { those who need their commitment to be } \\
\text { strengthened and /or can benefit and defend } \\
\text { Muslims. }\end{array}$ \\
\hline 5 & $\begin{array}{l}\text { Those in bondage } \\
\text { (riqab) }\end{array}$ & $\begin{array}{l}\text { Persons free themselves from bondages/slavery, } \\
\text { captives (war prisoners) and others in 'bondage } \\
\text { situations' who cannot afford the cost of their } \\
\text { freedom. }\end{array}$ \\
\hline 6 & $\begin{array}{l}\text { Those in debt } \\
\text { (gharimin) }\end{array}$ & $\begin{array}{c}\text { Persons who are in debt for personal or social } \\
\text { reasons but do not have sufficient assets/income to } \\
\text { pay off the debt. }\end{array}$ \\
\hline 7 & $\begin{array}{l}\text { Those in the cause } \\
\text { of God ( } \mathrm{fi} \\
\text { sabilillah) }\end{array}$ & $\begin{array}{l}\text { Persons who conduct actions/deeds which are } \\
\text { sincerely intended for the sake of God and Islam. }\end{array}$ \\
\hline 8 & $\begin{array}{l}\text { The wayfarer } \\
\text { (Ibnu sabil) }\end{array}$ & $\begin{array}{l}\text { Persons travelling (on missions that benefit the } \\
\text { public) and need help because they have } \\
\text { lost/consumed what they have. }\end{array}$ \\
\hline
\end{tabular}

Source: Summarized from Al-Qardawi (2000: 5-82)

In terms of share for each mustahik, most of Islamic jurists are in opinion that the share of each group is $1 / 8$ of zakah revenues. However, they also agree that the distribution of zakah should be prioritized to the poor and needy as they are the most disadvantaged people in society (Zaim, 2012). Moreover, it is suggested to distribute zakah proceeds immediately after receiving it from zakah payers (muzakki). According to Abu Hamam, this is so because zakah is basically relief to the poor; hence, it should be immediate for otherwise it does not fulfill its role (in Al-Qardhawi 2000). The jurists, however, still allow rooms for delay in some circumstances that may benefit either the payer or the designated recipients (Abdullah et al 2013).

Zakah proceeds are usually given in form of cash or goods directly distributed to the recipients, such as staple food and clothing, as practiced by the Prophet SAW and the successive ruling Caliphs (Al-Qardawi, 2000). In earlier literature, most of the zakah proceeds are given in forms of consumptive goods because majority of Islamic legal scholars are of the opinion that zakah is primarily intended for meeting the consumption and basic needs of the poor (in Kasri 213). However, more recently, Muslim scholars started to consider productive purposes of zakah distribution. It is suggested that zakah can be given as qard-hasan loan (in al-Qardawi 2000:634) or used for investment/productive purposes (Fiqh Academy, in Ahmed, 2004). 
Based on the literature, it could generally be suggested that there are two types of zakah distribution, namely consumptive-based and productive-based distribution. This categorization is used by some studies, such as Beik (2013), Ibrahim and Ghazali (2014) and Nurzaman (2016). It is also utilized by a number of studies/report, such as Indonesia Zakah Development Report (PEBS and IMZ, 2010), Islamic Social Finance Report (2016) and Indonesia Zakat Oulook (2017) albeit the term 'consumptive' is sometimes replaced with the term 'charity' purpose.

In his study, Beik (2013) investigates the economic role of zakah in reducing poverty and income inequality in Jakarta Indonesia. In analyzing the economic role, he divided the zakah disbursement programs into productive-based and consumptive-based programs. He referred to the former as the programs utilizing mudharabah and qard hasan method/contract, while the latter is defined as programs "dedicated for assisting those who are in needs". Similar categorization and definition are used by Nurzaman (2016) in his study about the impact of productive zakah in Jakarta. However, both studies did not elaborate the characteristics of each distributional approach implemented in the area of Indonesia.

Ibrahim and Ghazali (2014) provide a clearer explanation regarding the approach of zakah distribution in Malaysia. According to the study, there are two approaches of zakah distribution in Selangor state of Malaysia, namely consumptive and productive approach. Consumptive zakah distribution is given continuously for consumption purposes and for a relatively long period of time. It covers distribution in form of food, shelter, transportation, medicine and schooling expenses. On the other hand, productive zakah distribution is given for production purposes. This assistance is given to productive recipients to finance their economic projects for a long-term production and survival purposes. In a long term period, they are expected to become self-reliant and productive and able to pay zakah in return. Thus, unlike the consumptive assistance which is given continuously, productive assistance is given for a short period of time only. The main goal is for a productive and effective use of resources to eradicate poverty.

At this junction, two models of zakah distribution, i.e. consumptive and productive distribution could be suggested from the existing literature. However, particularly in the context of Indonesia, there is an indication that that the current literature has not provided sufficient information regarding characteristics of each approach. Arguably, this issue is important for at least three reasons. First, as zakah institution is expected to contribute in economic growth and poverty alleviation, improper use of zakah proceeds/revenues might result in failure to achieve the objectives of zakah institution. Second, misused of zakah funds might endanger trust and beliefs of Muslim society on the significance of zakah institution in Islamic teaching and Islamic society as zakah is one of the five pillars in Islam. Third, exploring approaches, practices and challenges in distributing zakah might provide important insights in increasing effectiveness of each approach and ultimately in achieving the objectives of zakah institution. These are the main issues explored and investigated in this study. 


\section{RESEARCH METHODOLOGY}

In exploring the management practices of zakah distribution implemented by zakah organizations in Indonesia, this study utilizes inductive and qualitative research approach. In this regard, primary data is obtained from semi structured interview with key person with managerial position in zakah agencies. In collecting the data, the interview protocol was initially sent to Director/Head of several large zakah organizations with a request to conduct the interview with Executives of the agencies. In the end, the author managed to interview 23 management personnel, mostly Directors and Operational Manager, of seven largest zakah organizations in Indonesia representing three types of zakah organizations in the country (i.e. government, corporate and private zakah agencies).

The data collected are analyzed by employing thematic analysis. Thematic analysis is defined as a method of organizing, describing, identifying, analyzing and reporting themes within qualitative data (Boyatzis, 1998). It is considered to be the most appropriate method for analyzing the qualitative data obtained from the semi-structured interviews due to its ability to summarize, interpret and compare the key features (themes) from a large qualitative data set. This method is widely used in organizational and management studies (Bryman \& Burgess, 2002; Cassell \& Symon, 2004; Miller, Dingwall, \& Murphy, 2004).

There are six phases in a thematic analysis, namely familiarization with data, generating initial codes, searching for themes, reviewing themes, defining and naming themes and finally producing the report (Braun and Clarke 2006). While all phases are important, coding is often seen as the primary process for developing themes within the raw data, through which important moments in the data are recognized and coded prior to interpretation. The code's interpretation can include comparing theme frequencies, identifying theme co-occurrences and graphically displaying relationships between different themes (Guest, et al., 2011).

In this study, with support of Nvivo9 software, thematic analysis is used extensively to identify approaches and evaluate practices and challenges in managing zakah distribution in Indonesia. Furthermore, since there are three types of zakah organizations in the country, analysis based on the organizational types are also conducted. Thus, in presenting the coding results, both the identity numbers of respondents (R1, R2, etc.) and the combination of the respondents' identities and the types of zakah agencies they represent (G1-1, G1-2, C1-1, etc.) are utilized. The results are described and analyzed in the subsequent sections.

\section{RESULTS}

Investigations into the approaches of distributing zakah in Indonesia lead to a general understanding that there are at least two main approaches of zakah distributions implemented by zakah institutions in the country. As shown in Table 2 , the approaches include the consumptive disbursement approach and the productive utilization approach. Each approach has several distinguishing features, particularly in relation to the purpose/expected impact, nature/types of programs and methods of distributing the proceeds. The categorization and general themes 
suggested above were inferred from the interviews ${ }^{1}$ as well as the different nature of the programs implemented under the approaches, which are explored in the next few tables.

Table 2 Distribution Approach

\begin{tabular}{ll}
\hline Interview Question & $\begin{array}{l}\text { How do you distribute the zakah proceeds? (i.e. what } \\
\text { are the approach of zakah distributions implemented } \\
\text { in your organization?) }\end{array}$ \\
\hline Focused Coding & Subthemes/Remarks \\
\hline 1 & Consumptive disbursement approach \\
\hline 2 & Productive utilization approach \\
\hline Concluding remarks & $\begin{array}{l}\text { Two approaches of zakah distribution were identified, } \\
\text { namely consumptive disbursement and productive } \\
\text { utilization approaches. }\end{array}$ \\
\hline
\end{tabular}

The consumptive approach is usually intended to provide immediate relief that serves the short-term needs of mustahik, which are commonly consumptive in nature (see Table 3). Typically, this type of distribution is associated with education, healthcare, social, religious and disaster relief programs. Under the model, a relatively small amount of money is usually distributed. However, for transparency and risk management purposes, some of the interviewees revealed that the money was increasingly given through bank transfer, paid directly to the relevant party or used to buy/provide the required items.

Table 3 Focused Coding 1 for the Distribution Approach

\begin{tabular}{ll}
\hline \multicolumn{1}{c}{ Subtheme } & \multicolumn{1}{c}{ Consumptive disbursement approach } \\
\hline Interview with & Remarks \\
\hline R7 (G2-5), R11 (C2- & $\begin{array}{l}\text { Provides immediate relief which primarily serves the } \\
\text { short-term need of mustahik }\end{array}$ \\
1), R14 (P1-1) & \\
\hline R7 (G2-5), R8 (G2-6), & Charity type of assistance \\
R10 (C1-2), R22 (P3- & \\
1) & \\
R1 (G1-1), R2 (G1-2), & Usually associated with education, healthcare, socio- \\
R4 (G2-2), R8 (G2-6), & religious and disaster relief programs. \\
R9 (C1-1), R10 (C1- & \\
2), R11 (C2-1), R14 \\
(P1-1), R19 (P1-6), \\
R21 (P2-1), R22 (P3- \\
1) \\
\hline R1 (G1-1), R8 (G2-6), \\
R11 (C2-1), R14 (P1- \\
1)
\end{tabular}

${ }^{1}$ It is notable that some of the agencies clearly used the term 'consumptive' and 'productive' distribution approach during the interview. For example, according to R7 (the executive of G2), "There are two principles for distributing zakah funds in our organization. First, we have the so-called charity or consumptive distribution. Second, we have those [distribution] that are productive in nature, which we call empowerment programs..." 


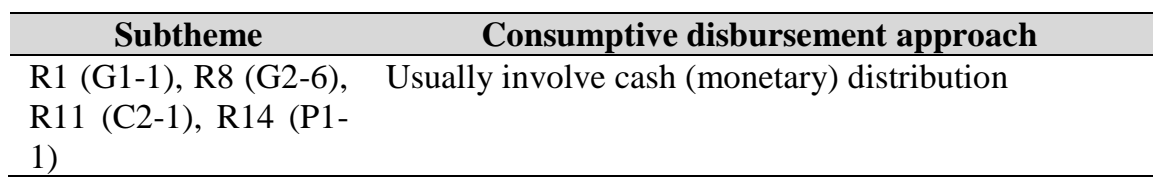

In contrast, the productive utilization approach aims to provide assistance that develops the long-term skills/capabilities of mustahik (see Table 4). The program is usually designed as charity with social mapping and priority. Under the program, the zakah recipients are expected to earn a higher income, experience better living conditions and eventually become more independent individuals/households. Hence, it is hoped that the productive activities will have longer-term and more sustainable impacts on the lives of the mustahik and their communities. This is clearly emphasized by one of the respondent from private zakah agency, R14 (P1-1), "Empowerment is usually done in economic program...usually the impact is relatively sustainable."

Table 4 Focused Coding 2 for the Distribution Approach

\begin{tabular}{l} 
Subtheme \\
Interview \\
with \\
\hline R3 (G2-1), Provide assistance that produces longer-term and more \\
R7 (G2-5), sustainable impacts on the mustahik and (sometimes) their \\
R9 (C1-1), communities \\
R10 (C1- \\
2), R12 \\
(C2-2), \\
R14 (P1- \\
1), R21 \\
(P2-1), \\
R22 (P3-1) \\
\hline R4 (G2-2), Charity with social mapping and priority (productive almsgiving) \\
R8 (G2-6), \\
R9 (C1-1), \\
R10 (C1- \\
2), R11 \\
(C2-1), \\
R14 (P1- \\
1), R21 \\
(P2-1), \\
R22 (P3-1) \\
R1 (G1-1), Usually associated with zakah utilization through economic and \\
R4 (G2-2), integrated/comprehensive programs \\
R8 (G2-6), \\
R9 (C1-1), \\
R11 (C2- \\
1), R14 \\
(P1-1), \\
R21 (P2- \\
\hline
\end{tabular}




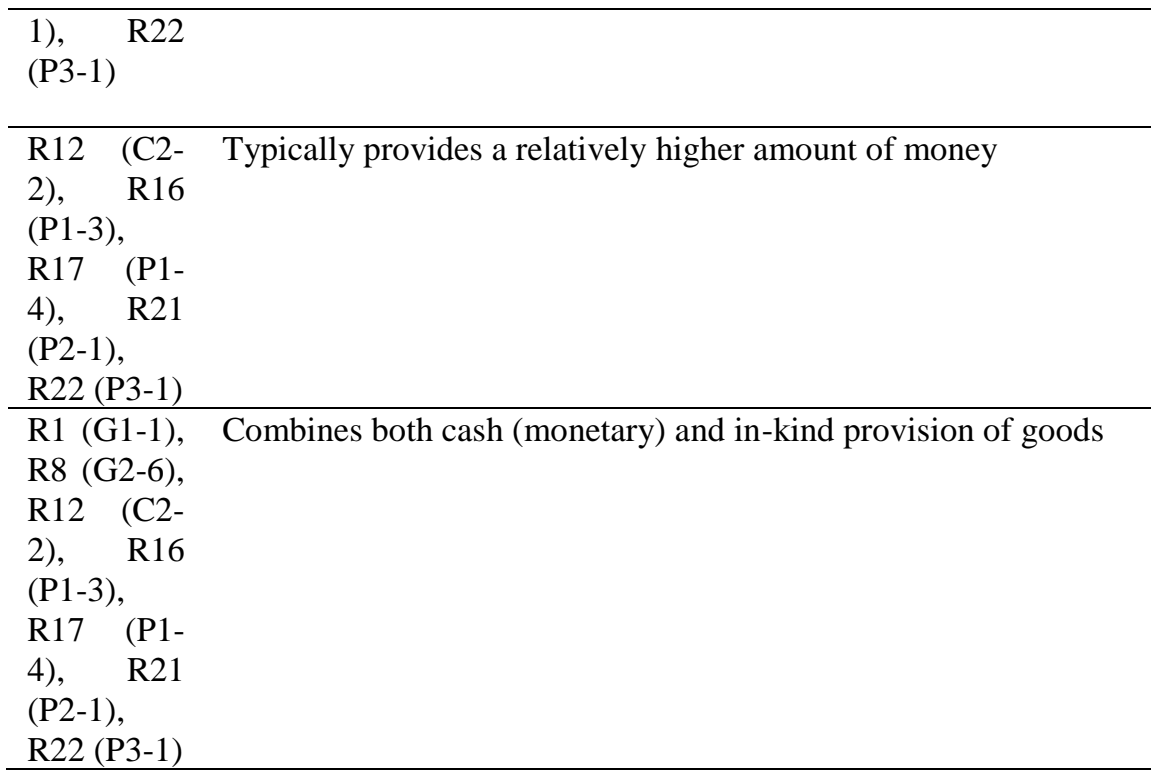

Furthermore, the productive model is usually associated with the economic and integrated (community development) programs which combine cash (monetary) and in-kind provision of goods/services to mustahik. With this approach, the amount of money distributed is usually higher than that of the noneconomic programs. An example of the program is the provision of productive goods such as agricultural machines, fertilizers, seed-livestock, sewing machines and wheel-barrows for small traders under the economic empowerment programs. Meanwhile, under the integrated programs, the productive goods are often contributed along with other assistance such as scholarships for children and health assistance for members of the mustahik family. The programs are mostly regular in nature and well-planned.

There are also some indications that different types of zakah organizations have focused on different approach in their zakah distribution programs. The private and corporate zakah agencies seem to focus on the productive approach, while the government agency seems to focus on the consumptive approach. In this respect, a corporate-based executive R9 (C1-1) stated that, "Because our affiliation is financial institution, we direct the programs into economic empowerment program... [to create] economic independency of ummah..." Another executive, R11 (C2-1) revealed that, "...our focus is indeed [Islamic] microfinance”. Meanwhile, CEO of P2 suggested that the focus of his organization was an integrated program combining economic empowerment (as main program) with other non-economic assistances. This type of program did not seem to be the focus of the government agencies, albeit it was also revealed during the interview that the government zakah agency (G2) has planned to implement the integrated program in the near future.

In addition to the main findings, there are some areas of concern with respect to the distribution of zakah proceeds. First, during the selection of zakah recipients, the existence of 'brokers of mustahik' and poor targeting of the zakah recipients were identified. The existence of the so-called 'brokers of mustahik', or 
the middle-men/women expecting to receive some kind of compensation for their 'services' in connecting the mustahik and amil (zakah agency), was recognized by the employees of G2 and C1. Furthermore, although rare, poor targeting of zakah in which the agencies provide assistance to 'undeserving' recipients or give assistance not needed/requested by the recipients was also found. ${ }^{2}$ Second, during the program implementation phase, threats from external parties were discovered. As explained by R9 (C1-1), the threat could come from 'loan sharks' who try to prevent potential mustahik from receiving zakah funds and from the 'traditional' Muslim scholars who prefer direct distribution of the zakah money. Finally, with respect to the zakah recipients or 'targets' covered by the distribution programs, it was recognized that there are 'untapped' potential to distribute the funds to a larger number of zakah recipients and to wider areas. These are some issues discovered from the interviews.

\section{DISCUSSION}

From the results presented in the previous section, it could generally be concluded that there are two approaches in distributing zakah proceeds/revenues in Indonesia, namely the consumptive disbursement approach and the productive utilization approach. Each approach has several distinguishing features, particularly in relation to the purpose/expected impact, nature/types of programs and methods of distributing the zakah proceeds. The characteristics of each approach are summarized in Table 5 .

Table 5 Approaches in Distributing Zakah Proceeds in Indonesia

\begin{tabular}{|c|c|c|}
\hline Characteristics & $\begin{array}{c}\text { Consumptive } \\
\text { Disbursement } \\
\text { Approach } \\
\end{array}$ & $\begin{array}{c}\text { Productive Utilization } \\
\text { Approach }\end{array}$ \\
\hline $\begin{array}{l}\text { Purpose/expected } \\
\text { impact }\end{array}$ & $\begin{array}{l}\text { Short-term programs } \\
\text { aimed to serve short- } \\
\text { term need }\end{array}$ & $\begin{array}{l}\text { Longer term programs aimed } \\
\text { to empower and create more } \\
\text { sustainable impacts }\end{array}$ \\
\hline $\begin{array}{l}\text { Types/nature of } \\
\text { program }\end{array}$ & $\begin{array}{lr}\text { Charity type } r \text { of } \\
\text { assistance; } & \text { usually } \\
\text { associated } & \text { with } \\
\text { education, healthcare, } \\
\text { socio-religious r and } \\
\text { disaster } \\
\text { programs. }\end{array}$ & $\begin{array}{l}\text { Charity with social mapping } \\
\text { and priority (productive } \\
\text { almsgiving); usually associated } \\
\text { with zakah utilization through } \\
\text { economic and } \\
\text { integrated/comprehensive } \\
\text { empowerment programs }\end{array}$ \\
\hline $\begin{array}{l}\text { Methods of } \\
\text { distributing } \\
\text { proceeds }\end{array}$ & $\begin{array}{l}\text { Usually involve cash } \\
\text { (monetary) } \\
\text { distribution; typically } \\
\text { distribute a relatively } \\
\text { small amount of } \\
\text { money }\end{array}$ & $\begin{array}{l}\text { Combines both } \\
\text { (monetary) and in-kind } \\
\text { provision of goods; typically } \\
\text { provides a relatively higher } \\
\text { amount of money }\end{array}$ \\
\hline
\end{tabular}

\footnotetext{
${ }^{2}$ These include, for instance, social assistance for rich widows and group-based economic assistance for wife of rich man.
} 
Under the consumptive disbursement approach, the main purpose is to serve immediate and short-term needs of mustahik. Typically, this includes provision of consumptive and short-term basic needs related to education (such as school expenses), healthcare (such as medical expenses) and socio-religious (including provision of food, shelter, transportation, prayers devices/facilities, etc.). It is also given to mustahik who are victims of natural and man-made disaster (such as victims of flood, earthquake, fire, etc.); thus, it is also distributed under disaster reliefs program. These kinds of distribution is consistent with the teaching of Islam as well as the practices of zakah distribution during the time of the Prophet SAW and the successive ruling Caliphs (Al-Qardawi, 2000; Ahmed 2004) as well as in contemporary Muslim societies as documented in many studies (see, among others, Beik 2013, Kasri 2013, and Ibrahim and Ghazali 2014). These types of distributions could be considered as the main objective and reason det're of zakah institution. Particularly when directed to the poor and needy, it becomes a must to be managed effectively.

With respect to the methods in distributing the zakah proceeds, the programs under the consumptive disbursement approach usually provide assistance in terms of cash (monetary) distribution and in relatively small amount. This 'contemporary' practice is slightly different with the earlier practices which focused on in-kind distribution. However, this is understandable because money is the major instrument/media of exchange today which provide convenience to people to do various transactions, including zakah payment. Furthermore, the money is usually distributed directly (i.e. cash on hand) to the recipients. However, as revealed during the interview, it was increasingly given through bank transfer, paid directly to the relevant party or used to buy/provide the required items ${ }^{3}$ in order to increase transparency and prevent misused of the funds. Hence, it becomes a part of risk management conducted by zakah organizations. Nevertheless, it is notable that in certain conditions and/or under certain program (such as disaster reliefs programs), the distribution could also be given in-kind. These methods of distributions have also been documented in earlier studies (Ibrahim and Ghazali 2014, Kasri 2015).

In contrast, under the productive utilization program, zakah proceeds are primarily given to provide assistance that develops the long-term skills/capabilities of mustahik with the main purpose to empower and create more sustainable impacts for the recipients. Under the program, the zakah recipients are expected to earn a higher income, experience better living conditions and eventually become more independent individuals/households. Hence, it is hoped that the productive activities will have longer-term and more sustainable impacts on the lives of the mustahik and their communities. These kinds of programs are consistent with zakah utilization through economic programs. Examples of such programs are the provision of working capital using Islamic contracts (particularly qard hasan loan) for small business and productive goods (such as agricultural machines, fertilizers, seed-livestock, and sewing machines and wheel-barrows) for small traders.

Arguably, such practices are rarely found in classical Islamic literature due to the conditions at that time which requires more consumptive-based supports for relieving immediate needs of the recipients (Al-Qardhawi 2000). However, the use

\footnotetext{
${ }^{3}$ For example, tuition fee invoice is often paid directly to school or given through bank transfer; medical cost is often paid directly to the hospital; etc.
} 
of zakah for productive purposes has been agreed by contemporary Muslim scholars. Al Maududi and Al Qardhawi, for instance, suggested the use of qard hasan from zakah revenues (al-Qardawi 2000:634). The Fiqh Academy of the OIC (Organization of Islamic Conference) also allowed the utilization of zakah funds for investment/productive purposes as it might help the mustahik, particularly the poor and needy, to escape poverty and empower them to be more productive (in Ahmed 2004). The impacts of such programs have been investigated by several studies cited earlier (see, for example, Beik 2013 and Kasri 2015), with a clear indication that the productive programs indeed provide more sustainable impacts to the recipients than the consumptive programs.

More recently, zakah organizations started to introduce the integrated/comprehensive economic empowerment programs. Under this program, economic assistance programs are combined with education/healthcare/social programs. Thus, cash assistances are provided alongside with in-kind zakah assistances. These kinds of programs were initially initiated as a response to the findings that cash zakah funds have been misused in certain cases. For example, cash working capital was used to pay for school fees or medical expenses, which was needed immediately by zakah beneficiaries. Later, it is also expected to provide more impacts for alleviating poverty of the recipients. By combining the programs, it is hoped that the recipients could use the cash-based economic assistance for its intended purpose because at the same time they also get additional supports from education/healthcare/social programs to meet their consumptive needs. Ultimately, in a longer term, it is hoped that such programs could result in more sustainable impacts and transformation of mustahik into muzakki.

Another main finding of the study indicates that there are differences in the approach of distributing zakah proceeds amongst different types of zakah institutions. In particular, it could be suggested that the government zakah agencies tend to implement the consumptive disbursement approach, whereas their nongovernment counterparts tend to implement the productive utilization approach. In this respect, it is argued that the distribution model is strongly affected by the agencies' affiliation. As mentioned earlier, a director of a corporate zakah agency mentioned that the focus on the economic program was primarily based on the fact that it is a social unit of an Islamic bank. Similar experiences were indicated by the zakah units of Islamic banks in other countries such as Faisal Islamic Bank and Nassir Social Bank in Egypt (Kahf, 2000). Likewise, the focus on social/education programs implemented by the government institution was related to the attempts to contribute to the authority's countrywide social program, which is mostly consumptive in nature. This style is predominantly implemented in countries where zakah is controlled by the government (Imtiazi, 2000).

In addition to the main findings, the existence of 'brokers' of mustahik and the poor targeting of zakah recipients were also identified. These problems have been documented in other countries such as Pakistan, Kuwait and Saudi Arabia (Al-Ajeel, 1995; Al-Sakran, 2001; Arif, 2006) and is said to be one of the main reasons for the ineffectiveness of the zakah institution in those countries. Tendency for 'ignorance' from the management of zakah organizations in Indonesia was also identified and believes to be potentially worsening the situation. ${ }^{4}$

\footnotetext{
${ }^{4}$ It is also notable from the interview that, according to R7 (G2-5), no legal actions were taken against the broker. When such cases occur, usually the brokers are simply advised not
} 
To solve the issue satisfactorily, it is necessary to plan and implement better strategies in selecting mustahik. For example, zakah organizations could create clearer mechanism and SOP for selecting mustahik for each type of zakah disbursement programs. Additionally, since one of the reasons of existence of such brokers are outreach and asymmetric and/or limited information regarding zakah organizations, it might be necessary for them to increase its outreach and information availability. This could be done, among others, by opening more offices/branches or providing an online platform which enable potential mustahik to directly apply for the assistance online. Arguably, the latter is increasingly important since today people are more connected online. More, since many studies discussing efficiency of zakah organization noted on possible higher costs of opening office or additional branches of zakah organizations (see, for example, Noor et al 2015), the online platform could potentially increase efficiency of managing a zakah organization.

Other interesting findings are threats from external parties and tendency for 'competition' in distributing zakah funds. The threat from 'loan sharks', who try to prevent potential mustahik from receiving zakah funds, is usually related to the capital support from zakah organization through its Islamic microfinance programs. This finding is quite surprising, since loan sharks are usually considered as 'competitor' of banks or other formal financial institutions. However, as zakah organizations also offer financial supports for the poor and needy, apparently they also compete head to head with the loan sharks who are making profit from their business. Furthermore, 'threat' from traditional Muslim scholars, such as traditional kiyai who prefer the zakah money to be distributed directly to the poor regardless of the recurrent negative social impacts created by such a distribution style, is also evident. ${ }^{5}$ However, different from the loan sharks, the kiyai did not look for profit in their actions.

In this regard, it is firstly suggested to continuously educate the external parties regarding the importance and expected impacts of zakah distributed through formal zakah institutions, particularly in providing reliefs and reducing poverty of the poor. This might not be something easy, especially for the loan sharks who are making profit from their business. Therefore, it has to be done together with other relevant parties such as government and academic institution. Furthermore, since it is clear that many poor people deserving zakah recipients are in need of working capital (which sometimes they get from the loan sharks), it might be necessary to increase allocation to productive zakah assistance and enhance the system to reach the poor. Zakah organizations could also consider establishing zakah-based Baitul Maal wat Tamweel or other similar institutions. All in all, relevant strategies to increase outreach and impacts of zakah distribution could be considered by zakah organizations to enhance their effectiveness in distributing zakah proceeds.

to do it again. Furthermore, for the case of poor targeting, R14 (C1-1) believed that they should be considered simply as 'marginal errors' in the selection process because, at some point, all zakah agencies experienced these problems.

${ }^{5}$ The negative social impacts, such as 'riots' and casualties during the direct distributions of zakah, occur almost every year in Indonesia. However, such a distribution style continues to be practiced in society. 


\section{CONCLUSION}

Based on the findings and analysis explained above, a number of conclusions could be derived. First, zakah distribution in Indonesia follows consumptive disbursement and productive utilization approaches. Each approaches is different in terms of purpose/expected impact, types/nature of programs and methods of distributing the zakah proceeds. Second, different types of zakah organizations tend to focus on different approach in distributing zakah, albeit there is a trend of divergence towards the productive approach. Finally, some challenges are identified particularly in relation to selection/coverage of mustahik and threat/competition in distributing zakah funds.

From the study, it could be suggested that productive utilization approach is increasingly important in zakah distribution, particularly in achieving poverty alleviation goals. Importance of enhancing outreach and availability of information related to zakah programs (including through online platforms) are also emphasized to reduce selection/targeting problems. Educations and advocacies to all zakah stakeholders, particularly (traditional) Muslim scholars and Muslim society (one of which might have profession as loan sharks), also need to be conducted continuously. Overall, it is expected that the strategies could enhance effectiveness of zakah distribution and ultimately support zakah institution in achieving its noble objectives.

\section{References}

Abdullah, L. H., Ahmad, W. M. W., Rahman, N. N. A., Ali, A. K., Nor, M. R. M., Khalil, S. A., \& Al-Nahari, A. A. A. Q. (2012). Juristic discourse on the delay in payment and distribution of zakat. Middle-East Journal of Scientific Research, 12(2), 176-181.

Ahmed, H. (2004). Role of zakah and awqaf in poverty alleviation. Jeddah: Islamic Development Bank, Islamic Research and Training Institute.

Al-Ajeel, A. Q. D. (1995). Zakah Administration in Kuwait. Institutional Framework of Zakah: Dimensions and Implications. In A. El-Ashker and M. Haq (editor), Jeddah, Islamic Research and Training Institute, Islamic Development Bank.

Al-Qardhawi, Y. (2010). Fiqh al-zakat. Jeddah: Scientific Publishing Centre of King Abdul Aziz University.

Al-Sakran, S. (2001). "Leverage determinants in the absence of corporate tax system: the case of non-financial publicly traded corporations in Saudi Arabia." Managerial Finance 27(10/11): 58-86.

Arif, G. (2006). Targeting Efficiency of Poverty Reduction Programs in Pakistan. Manila, Asia Development Bank.

Beik, I. S. (2013). Economic role of zakat in reducing poverty and income inequality: A case study in the Province of DKI Jakarta, Indonesia. LAP Lambert Academic Publishing. 
Boyatzis, R. E. (1998). Transforming qualitative information: Thematic analysis and code development. London, Sage Publications.

Braun, V. and V. Clarke (2006). "Using thematic analysis in psychology." Qualitative research in psychology 3(2): 77-101.

Bryman, A. and B. Burgess (2002). Analyzing qualitative data. London, Routledge.

Cassell, C. and G. Symon (2004). Essential guide to qualitative methods in organizational research. London, Sage.

Guest, G., K. M. MacQueen, et al. (2011). Applied thematic analysis. London, Sage.

Ibrahim, P., \& Ghazali, R. (2014). Zakah as an islamic micro-financing mechanism to productive zakah recipients. Asian Economic and Financial Review, 4(1), 117.

Imtiazi, I. (2000). Introduction. Management of Zakah in Modern Muslim Society. I. Imtiazi, M. Mannan, M. Niaz and A. Deria. Jeddah, Islamic Research and Training Institute, Islamic Development Bank: 1-28.

Indonesia Zakat Outlook 2017 (2016), Jakarta: BAZNAS.

Islamic Social Finance Report 2015 (2016), Jeddah: IRTI-IDB and Thomson Reuters.

Kahf, M. (2000). Zakah management in some Muslim societies. Islamic Research and Training Institute, Islamic Development Bank.

Kasri, R. (2013). "Giving Behaviors in Indonesia: Motives and Marketing Implications for Islamic Charities." Journal of Islamic Marketing 4(3): 66.

Kasri, R., \& Ahmed, H. (2015). Assessing Socio-Economic Development based on Maqāșid al-Sharī'ah Principles: Normative Frameworks, Methods and Implementation in Indonesia. Islamic Economic Studies, 23(1), 73-100.

Miller, G., R. Dingwall, et al. (2004). Using qualitative data and analysis: Reflections on organizational research. London, Sage.

Noor, A. H. M., Rasool, M. S. A., Ali, R. M. Y. S. M., \& Rahman, R. A. (2015). Efficiency of Islamic Institutions: Empirical Evidence of Zakat Organizations' Performance in Malaysia. Journal of Economics, Business and Management, 3(2), 282-286.

Nurzaman, M. S. (2016). Evaluating the Impact of Productive Based Zakat in The Perspective of Human Development Index: A Comparative Analysis. Kyoto Bulletin of Islamic Area Studies, 44-62.

Obaidullah, M., \& Shirazi, N. S. (2014). Integrating Philanthropy with Microfinance: Models of Community Empowerment. In Social Impact Finance (pp. 75-96). Palgrave Macmillan UK. 
PEBS-FEUI and IMZ (2010). Indonesia Zakat and Development Report 2010. M. E. Nasution, N. Mintarti, A. Juwainiet al. Jakarta, PEBS-FEUI and IMZ.

Saad, R., \& Haniffa, R. (2014). Determinants of zakah (Islamic tax) compliance behavior. Journal of Islamic Accounting and Business Research, 5(2), 182-193.

Samad, A., \& Glenn, L. M. (2010). Development of Zakah and Zakah coverage in monotheistic faiths. International Journal of Social Economics, 37(4), 302-315.

Sari, M. D., Bahari, Z., \& Hamat, Z. (2013). Review on Indonesian zakah management and obstacles. Social Sciences, 2(2), 76-89.

Shaikh, S. A., \& Shaikh, S. A. (2017). Poverty alleviation through financing microenterprises with equity finance. Journal of Islamic Accounting and Business Research, 8(1), 87-99.

Zaim, S. (2000). Recent Interpretations of the Economic Aspects of Zakat. Management of Zakah in Modern Muslim Society. I. Imtiazi, M. A. Mannan, M. Niaz and A. Deria. Jeddah, Islamic Research and Training Institute, Islamic Development Bank: 101-120. 